also a menace to health. In many workshops the dust impairs the quality of the finished goods. The floor-waxing machine with suction device should prove specially useful in hotels, hospitals and sanatoriums.

\section{Industrial Physics}

THE address which Dr. Paul D. Foote delivered before the American Physical Society as retiring president appears in full in the February issue of the Review of Scientific Instruments. In it he points out how inadequately industrial physics has been represented on the Council of the Society, and how as a consequence much of the work of the members of the Society has failed to attract the attention of industrial executives and they are unable to see that there are places for physicists in their organisations. It has been left to large corporations like the General Electric Company to show how much physicists can do for industry. Dr. Foote considers that the training in physics in most of the American universities fits a man neither for industry nor for a position in a junior college, and that industry has to look to the engineering rather than to the physics departments for men adequately trained in the fundamentals of classical physics in preference to those superficially acquainted with the latest developments of quantum mechanics. He hopes that the newly-formed American Institute of Physics and the new journal Physics will secure more intimate contact between physics and industry, and that the attitude of the Society towards applied physics in the next few years will insure that physics becomes a real profession rather than an academic avocation. Since the foundation of the Institute of Physics, in London in 1918, the position of British physicists has improved. Lord Rutherford recently pointed out thàt there has been a rapidly growing recognition of the importance of the physicist, not only in the academic world but also in industry, and he considers that the Institute of Physics can justly claim some of the credit for this.

\section{Tests for Accident Proneness}

UNDER the title "Tests for Accident Proneness", the Industrial Health Research Board has published the results of a further investigation into the factors involved in "accident proneness" which have engaged its attention for several years (Medical Research Council : Industrial Health Research Board. Report No. 68 : Tests for Accident Proneness. Pp. iv +37. London : H.M. Stationery Office, 1933. 9d. net). Previous work had established that certain individuals are inherently more liable to sustain industrial accidents than others exposed to the same risk. By the investigations of E. Farmer, E. G. Chambers and F. J. Kirk now reported, it has been established from experiments with groups of dockyard apprentices and naval artificers that, within the groups studied, poor æsthetokinetic co-ordination (defined as the ability to do certain sensori-motor tests) is associated with a liability to sustain an undue number of accidents. The results do not suggest that æsthetokinetic coordination is associated with accident proneness in all occupations, although it is probably associated with it in groups doing similar work to those tested. Deficiency in this function, however, only accounted for a part of the accidents sustained, and it is evident that only one of the factors involved in accident proneness has thus far been isolated and evaluated. Even this, however, makes a definite step towards the practical goal of detecting beforehand those specially liable to accident and warning them against entering dangerous occupations. No significant relation was observed between intelligence and accidents in any of the groups, and in two of them accident proneness did not decrease with age and experience. It does not follow, however, that in groups employed on different work, variations in intelligence may not play a part in accident proneness.

\section{Scientific Survey of South-Eastern Polynesia}

The Bernice P. Bishop Museum, Honolulu, has organised an expedition, to be known as the Mangareva Expedition, for the study of the little-known parts of south-eastern Polynesia. Because other means of transportation are unavailable, the Expedition is provided with two ships. The Islander (Capt. W. G. Anderson), a high-powered sampan, was to leave Honolulu on March 1 and during a six months' cruise will serve as a 'master ship' for scientific workers who will conduct investigations chiefly at Mangareva, Oeno, Pitcairn, Rapa, Tubuai, Rurutu, Raivavae, and Rimitara islands. The second ship, the cutter yacht Tiare Tahiti (Capt. Robert S. Burrell), under charter from May until October, will serve primarily as a 'transfer ship' for the ethnologists at work in Mangareva and among the three hundred and sixty islands of the Tuamotu Archipelago. The chief purpose of the Expedition is to record the data regarding native races, flora and land fauna, which are disappearing at a surprisingly rapid rate. Incidental observations on geology, marine zoology and general oceanography will also be made. The scientific staff includes Dr. Peter $\mathbf{H}$. Buck, Kenneth P. Emory and J. Frank Stimson, ethnologists ; Prof. Harold St. John and Raymond Fosberg, botanists; Dr. C. Montague Cooke, Jr., and Donald Anderson, malacologists; and E. C. Zimmerman, field entomologist. Dr. C. Montague Cooke, Jr., has been appointed leader of the Expedition.

\section{A History of Vegetables}

The Gardeners' Chronicle of March 3 publishes a report of a lecture on "The Introduction of Vegetables" by Mr. E. A. Bunyard. It comes as somewhat of a surprise to find that many of our common vegetables were once regarded as harmful plants, or were the subjects of religious prohibition. The broad bean, for example, was forbidden to the Egyptian priests, though later it was the cause of 'bean-feasts' to a bean god. Garlic, cabbage, asparagus and spinach have all had a somewhat chequered history. The scarlet runner bean was long prevented from becoming a table delicacy by its value for ornamental purposes. Tomatoes were first suspected of being poisonous, then became medicinal, and it was not until the 'eighties of last century that their nutritive 